\section{ВТОРЖЕНИЕ КИТАЙСКОГО И МОНГОЛЬСКОГО ОТРЯДОВ В ТУВУ (1918-1919 гг.)}

\author{
Аяна А. Самдан \\ Тувинский институт гуманитарных \\ и прикладных социально- \\ экономических исследований, \\ Российская Федерация
}

\section{THE INVASION OF TUVA BY CHINESE AND MONGOLIAN ARMY UNITS (1918-1919)}

\author{
Ayana A. Samdan \\ Tuvan Institute for Humanities and \\ Applied Social and Economic Studies, \\ Russian Federation
}

После установления протектората России над Урянхайским краем в 1914 г., последовали попытки введения российской административной системы и судоустройства, которые не всегда учитывали особенности устоявшегося внутреннего самоуправления тувинцев.

Революции 1917 2. в России, последовавшая за ними гражданская война имели свое влияние и на Туву, обострив без того сложную политическую ситуацию. Свою лепту в это внесли Ургинское и Пекинское правительства, которые действовали согласованно по занятию территории Тувы. Была проведена подготовительная работа непосредственно рядом с пограничной линией и в 19192. в Туву проникли вооруженные отряды китайцев и монголов, которые бесплатно пользовались продовольствием и подводами, а местное население участвовало в мобилизации людских ресурсов. Омское правительство было не в состоянии оказать какую-либо существенную помощь.

В статье на основе архивных документов и ряда работ российских и зарубежных исследователей предпринята попытка уточнения причин, хода и результата вооруженного конфликта.

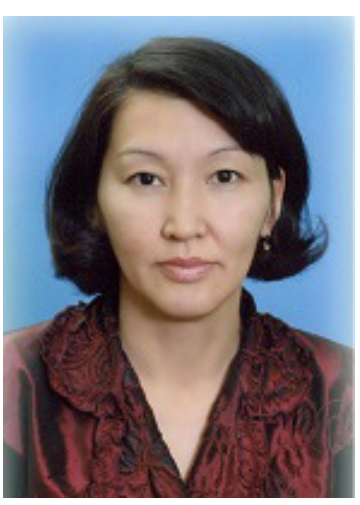

The establishment of protectorate over Tuva by Russia in 1914 was followed by attempts to introduce Russian administrative and judicial system, which did not always take due account of characteristic features of a wellestablished internal self-governance of Tuvans.

The 1917 revolutions in Russia and the civil war that immediately ensued also had an influence on Tuva, exacerbating the already complicated political situation. The Urga and Peking governments made their contribution to this by taking concerted action to capture the territory of Tuva. The groundwork for military action was laid in close proximity to border line, and in 1919 Tuva was invaded by armed units of the Chinese and Mongolians, who used foodstuffs and carts requisited from local people to replenish supplies and recruited local population to reinforce their troops. The Omsk Government was unable to provide any substantial help.

The article, based on archival studies and a series of contributions of Russian and international scholars, attempts to offer a number of insights into the reasons, course, and outcome of this armed conflict.

Самдан Аяна Анай-ооловна - кандидат исторических наук, заведующая сектором истории Тувинского института гуманитарных и прикладных социально-экономических исследований. Адрес: 667000, Россия, г. Кызыл, ул Кочетова, д. 4. Тел.: +7 (39422) 2-39-36. Эл. адрес: camayana@mail.ru Samdan Ayana Anay-oolovna, Candidate of History, Head of Sector of History, Tuva Institute for the Humanities and Applied Social and Economic Studies. Postal address: 4 Kochetov St., 667000 Kyzyl, Russian Federation. Tel.: +7 (39422) 2-39-36. E-mail: camayana@mail.ru 
Ключевые слова: Тува; история Тувы; Урянхайский край; монголы; китайцы; протекторат; мобилизация; Содном-Балчир; дружинники; Белоцарск; революция 1917 года; гражданская война
Keywords: Tuva; history of Tuva; Uriankhai krai; Mongols, Chinese; protectorate; mobilization; Sodnom-Balcer; vigilantes; Belotsarsk; revolution of 1917; civil war

\section{Введение}

В настоящее время в Российской Федерации широко отмечается 100-летие Октябрьской революции 1917 г. в России. В связи с этим актуальными становятся вопросы гражданской войны и иностранной интервенции в Туве, последовавшие за революцией в России.

В историографии изучаемой темы можно выделить два периода. И в том и в другом случае ученые разрабатывали проблему Тувы в контексте взаимоотношений с Россией, Монголией и Китаем. В 1956 г. вышел сборник воспоминаний участников революционных событий И. Г. Сафьянова, А. Д. Кравченко, П. Е. Щетинкина и С. К. Кочетова, подготовленный Х. М. Сейфулиным (Сейфулин, 1956). Впервые попытка серьезного научного осмысления была предпринята в работах В. Ч. Очура, который, привлекая обширную базу архивных источников, изучил основные этапы вторжения в Туву китайских, монгольских отрядов, колчаковской и Красной армий (Очур, 1967). В последующие годы рассматриваемую проблему затрагивали в своих работах Ю. Л. Аранчын, Н. А. Сердобов (Аранчын, 1982; Сердобов, 1985). В постсоветский период в разработку темы включились и засаянские ученые: Е. А. Белов и Г. В. Дацышен (Белов, 1999; История Тувы, 2007: 87-95), которые в рамках смежных тем раскрыли всю сложную и противоречивую картину. Таким образом, была проведена большая работа по осмыслению и систематизации фактического материала.

Тем не менее, остается ряд не до конца решенных вопросов рассматриваемой нами проблемы. В данной статье на основе архивных документов и ряда работ российских и зарубежных исследователей предпринята попытка уточнения причин, хода и результата вооруженного конфликта 1918-1919 г.

\section{Административное и судебное переустройство Тувы после уста- новления российского протектората}

Установление протектората России над Тувой в 1914 г. стало возможным благодаря усилиям заведующего пограничными делами Усинского округа А. П. Церерина. В то время отдельные тувинские хошуны и сумоны входили в состав двух аймаков соседней Монголии или же были шабинарами Джалханзахутугты, т. е. в административном отношении Тува была разрозненной, а «выс- 
шее лицо в иерархии чиновников амбын-нойон Комбу-Доржу не обладал достаточным авторитетом, чтобы объединить под властью всю Туву» (Моллеров, 2014: 17). Чтобы минимизировать монгольское влияние, А. П. Церерин «беспрепятственно удалил ...всех монгольских чиновников» (Собрание архивных документов ..., 2014: 156). А правителем Бээзи хошуна стал тувинец К. Чымба, которому был присвоен шарик первой степени, а над сумонами Маады и Чооду поставили человека в должности тэргуун-дзайсана (главный дзайсан). Уже в августе 1914 г. А. П. Церерин докладывал Иркутскому генерал-губернатору о том, что он в несколько этапов провел процедуру объявления тувинским нойонам об установлении российского протектората.

В ноябре 1914 г. комиссаром по делам Урянхайского края был назначен В. Ю. Григорьев, который сразу активно занялся переустройством Тувы. Он писал: «...Конец Урянхаю и урянхам (тувинцам. - A. C.)! Через 2-3 года здесь будет две-три русских волости, столько же инородческих (сойотских), а сам Урянхайский край будет называться частью Минусинского уезда Енисейской губернии!» (цит.: Сафьянов, 2012: 102).

Русские власти стали предпринимать меры по изменению административной структуры и судебной системы, которые были направлены на унификацию российской имперской системы управления, не всегда учитывающую особенности устоявшегося внутреннего самоуправления тувинцев (см.: Самдан, 2014). Весной 1915 г. В. Ю. Григорьев обманным путем отобрал печать у правителя Тувы Комбу-Доржу, а затем вовсе отстранил его и назначил своего человека. Но Агван-демчи, ставленник В. Ю. Григорьева, был вскоре убит неизвестными на перевале Калдак-Хамар. Кроме того, В. Ю. Григорьев с отрядом казаков пытался арестовать правителя Тоджинского хошуна Тогмида, но ему в последний момент удалось вырваться, а «Григорьеву досталась только шапка Тогмида с красным шариком...» (Сафьянов, 2012: 103).

Введение российской судебной системы в Туве так и не прижилось. Тувинцы не доверяли и опасались обращаться к русскому суду, поскольку «туземцы больше всего боятся Минусинской тюрьмы, где они быстро и в большом относительно числе погибают» (История Тувы, 2007: 38). За три года в Минусинской тюрьме погибло около 30 тувинцев. Тогда в 1915 г. было разработано «Временное положение о смешанном суде между русскими и урянхайцами», которое предусматривало коллегиальное принятие решений, апелляционность, выборность судей (4 судьи на паритетной основе из русских и тувинцев и председатель, назначаемый комиссаром), публичность судопроизводства.

\section{Китайско-монгольское совещание в Урге}

После двух революций 1917 г. в России, отречения от власти Николая II и государственного переворота, большинство тувинских нойонов заявили о пре- 
кращении действия российского протектората в Туве. Вновь начались метания и тувинские нойоны изъявили желание примкнуть к монголам.

В конце 1917 г. в Урге состоялось совещание между китайцами и монголами, в котором последние ссылаясь на ст. 11 Кяхтинского тройственного договора 1915 г., считали Урянхайский край «нераздельной частью Автономной Внешней Монголии» (Государственный архив Республики Тыва - далее ГАРТ. Ф. 112. Оп. 1. Д. 115. Л. 8). Было принято решение оправить в Туву своих представителей, а в случае необходимости и вооруженные отряды. В Туву китайцы отправили своего представителя Ян-Ши-чао, выпускника юридического факультета Петербургского университета и занимавшего должность заведующего канцелярии китайского резидента в Урге.

Монгольское правительство назначило своим представителем в Туве китаефила Итгемжит-бейсэ Цогт-Очира. Он, будучи представителем Монгольского правительства в Кяхте, проявил себя «непримиримым противником развития русского дела в Монголии и сторонником китайцев» (ГАРТ. Ф. 112. Оп. 1. Д. 115. Л. 5). Сопровождать Цогт-Очира назначили религиозного деятеля Чин-Сужигт Номун-хана Цэдэнбалжира и военного помощника - гуна Дашравдана. Как видим, для оказания влияния на местное население монголы решили воздействовать через религию и в случае необходимости были готовы применить силовое давление.

Осенью 1918 г. Ян-Ши-чао в сопровождении вооруженного конвоя, состоявшего из 20 солдат, выехал из Урги. Однако, в Улангоме он, узнав о стягивании русской военной силы в Урянхае, сообщил об этом в Ургу и был вынужден остаться здесь перезимовать, ожидая ответа. В начале декабря на помощь ЯнШи-чао прибыли 5 эшелонов китайских войск по 30 человек в каждом (3 эшелона были сформированы в Урге и по одному в Кобдо и Улясутае) с 4-мя горными орудиями и 7 пулеметами. «Каждый эшелон сопровождался военным грузом и провиантами» (ГАРТ. Ф. 112. ОП. 1. Д. 115. Л. 16об.).

Китайцы не теряли зря время. В январе 1919 г. минуя русские посты в Самагалтае появился китайский отряд из 25 человек под командованием Хуана. Он провел совещание с участием тувинских чиновников, в результате которого Соднам-Балчир был избран «правителем над захребтинскими урянхами» (ГАРТ. Ф. 112. Оп. 1. Д. 115. Л. 215). Как доносил Кобдинский консул А. П. Хионин: «Хуан лично устроил на Самагалтае церемонию приема урянхов - состав Ойнарского хошуна - в подданство Китайской Республики и вручил печать амбаня сыну Гомбодоржи» (ГАРТ. Ф. 112. Оп. 1. Д. 115. Л. 13). Также было приказано организовать мобилизацию только что «принятого в подданство» населения на военную службу в количестве более 100 человек. Обратно в Улангом Хуан поехал уже вместе с Соднам-Балчиром. Там он был представлен перед Ян-Ши-чао. Между тем последний находясь в Улангоме посылал письма русским властям Тувы, в котором он выдавал себя за командированного «с небольшим конвоем для ока- 
зания покровительства торговли, нашим торговцам в Урянхае» (ГАРТ. Ф. 112. Оп. 1. Д. 271. Л. 5). Под видом «защиты интересов своих торговцев» он пытался провести «мирные переговоры» на территории Тувы. Тем временем в Улангоме китайцы продолжили готовиться к вооруженному выступлению, а с местного населения приказали мобилизовать 180 лошадей для солдат и 100 верблюдов для погрузки провизии и военного груза.

Монголы же ускорили отъезд Цогт-Очира с 20-ю солдатами в Улангом, чтобы он встретился там с китайским представителем. Цогт-Очир по прибытии объявил о мобилизации людей, лошадей и провизии с близлежайших монгольских аймаков и округов. Но, по словам очевидца, мобилизованный монгольский отряд «не только не обучен военному искусству и стрельбе, но и даже не умеет обращаться с огнестрельным оружием» (ГАРТ. Ф. 112. Оп. 1. Д. 115. Л. 24).

\section{Военная помощь из Омска}

Русские власти Урянхая, боясь внезапного вторжения китайско-монгольского отряда, немедленно докладывали об угрожающей опасности в Омск и Иркутск, и просили дополнительной военной помощи. Омское правительство отправило шестую сотню 3-го сибирского казачьего полка с полным снаряжением и вооружением под командованием есаула К. Распопина. Последнему и всем другим русским было приказано избегать вооруженных столкновений с китайцами и монголами, а также «не следует вести с ними официальных сношений» (ГАРТ. Ф. 112. Оп. 1. Д. 271. Л. 6). Как предполагал А. А. Турчанинов, китайцы будут стараться вызвать вооруженное столкновение, «чтобы его можно было раздуть и ввести войска в Монголию. Урянхай предлог, приз - Монголия» (ГАРТ. Ф. 112. ОП. 1. Д. 271. Л. 6).

Тем временем А. П. Хионин информировал А. А. Турчанинова, который был назначен после В. Ю. Григорьева, о передвижении китайских и монгольских войск. «Китайцы и монголы, - телеграфировал консул, - начали постепенно продвигаться к урянхайской границе с целью проникнуть в Урянхай. Первые продвигаются к перевалам Хандагайту и Торгалыг (Чыжыргана), а вторые к Самагалтаю и Амбан-куре» (ГАРТ. Ф. 112. Оп. 1. Д. 90. Л. 93об.). Получив данное сообщение, А. А. Турчанинов предпринял меры, чтобы не допустить китайцев и монголов в Туву и организовал русские казачьи посты вдоль границы с Монголией. Этот факт несколько усмирил пыл китайцев.

А. А. Турчанинов, получив очередную телеграмму от А. П. Хионина о передвижении китайцев в сторону Тувы, уже в панике стал просить помощи из близлежащих городов Минусинска и Усинска «с достаточным запасом патронов и по возможности пулеметами» (ГАРТ. Ф. 112. Оп. 1. Д. 90 Л. 35об). Но он так ее и не дождался. Тогда были созданы отряды дружинников из переселенцев, 
которые должны были охранять основные стратегические дороги к Белоцарску. В районы Тувы были командированы лица для организации дружин, разведки. Дружинами командовали прибывшие из первой Минусинской роты офицеры и отставные военные, находящиеся на службе в Переселенческом управлении.

Комиссар предупредил русское население Тувы о вооруженном вторжении со стороны Монголии с оговоркой «держать в секрете, в особенности от сойотского (тувинского) населения» (ГАРТ. Ф. 112. Оп. 1. Д. 90), видимо, опасаясь беспорядков.

\section{Вооруженное столкновение}

В конце февраля 1919 г. китайский вооруженный отряд из 118 солдат вторгся, как и информировал кобдинский консул, в юго-западную часть Тувы через пост Чыжыргана. Русский пост был взят без труда после кратковременной перестрелки. Вслед за китайцами была послана дружина под командованием хорунжия Делибалта, который обнаружил отряд уже около Верхнечаданского хурээ. Здесь 1 марта состоялось вооруженное столкновение, который продолжился почти 12 часов с перерывами на переговоры. Как докладывал Делибалт: «Слабо обученных и необстрелянных дружинников приходилось загонять на линию огня только револьвером и тупым концом шашки» (ГАРТ. Ф. 112. Оп. 1. Д. 90. Л. 96). В результате китайский отряд был вынужден отступить, потеряв при этом убитыми 7 человек и 6- раненными. Русским же достались 1 пулемет системы Максим, около 30 тысяч патронов и 50 винтовок. «В связи с поражением монголо-китайско-урянхайского отряда под Чаданским хурэ в марте 1919 г. глава внешнеполитического ведомства монгольского правительства Цэрэндоржи направил ноту представлявшему в Монголии интересы омского правительства А. А. Орлову с требованием наказать русских, убивших и пленивших китайских и монгольских солдат» (История Тувы, 2007: 92).

Тем временем монголы с Улангома перекочевали с начала в «Гандан-хурээ на p. Тэс, а затем, оставив там воинские резервы, передвинулись северо-западнее и расположились в хошуне баитского Баньди-бейле около устья р. Тэса при впадении его в оз. Убса-нур с восточной стороны» (ГАРТ. Ф. 112. Оп. 1. Д. 115. Л. 24). Между тем Цогт-Очир занимал пассивную позицию, чего не скажешь о монгольском религиозном деятеле Номун-хане Цэдэнбалжире. Цогт-Очир рядом с границей с Тувой тайно встретился Соднам-Балчиром и сообщил ему о том, что «урянхи согласно соглашения высших правительств России и Монголии должны быть переданы Монголии» (ГАРТ. Ф. 112. Оп. 1. Д. 269. Л. 115). Видя концентрацию военных русских в Туве Цогт-Очир так и решился войти на территорию Тувы и попросил отставку, мотивируя тем, что «не знаком с организацией военного дела». 


\section{Попытка объединения}

Номун-хан 25 февраля 1919 г. в Самагалтае созвал совещание, где присутствовали почти все чиновники Оюннарского хошуна. Видя разрозненность последних, когда каждый правитель сумона самоопределялся по своему желанию, Номун-хан заставил всех объединиться под управлением Соднам-Балчира. Монголы заручились поддержкой последнего, который обещал провести отряд «перевалами и тропами на Хемчик, минуя русские посты» (Белов, 1999: 164). Но у них не хватало лошадей и оружия, поэтому в Хендерге хурээ был отправлен Ромбо-гэгээн. Там он также собрал представителей тувинской элиты и лам, где было принято решение собрать 200 лошадей для китайских и монгольских отрядов (там же). Узнав об этом, А. А. Турчанинов срочном порядке дал распоряжение штабс-капитану Г. И. Бочкареву, который нес службу в Подребтинской районе, предложить Ромбо-гэгээну покинуть пределы Тувы, что и было сделано.

Видя огромное скопление тувинцев вокруг монгольских религиозных деятелей, А. А. Турчанинов назначает духовным религиозным лидером в должности «Бандидо хамбо-ламы Урянхайского края» Монгуша Лубсан-Чамзы, который был убежденным сторонником русских. «Образованный, энергичный, - писал в представлении А. А. Турчанинов, - с ясным взглядом на вещи, пользующийся заслуженным уважением как среди духовенства, так и населения страны Чжамцо хамбо-лама лучше кого бы то ни было сможет в настоящий трудный момент для России объединить Урянхайское духовенство и через его посредство своим авторитетом воздействовать на туземное население всех хошунов в пользу России» (ГАРТ. Ф.112. Оп. 1. Д. 296. Л. 6).

\section{Назначение Хатанбатора Максаржава}

После отставки Цогт-Очира, в марте 1919 г. на его место назначили Хатанбатора Максаржава. Вместе с ним был отправлен буддийский перерожденец Дилопа-хутугта. Максаржав за короткий срок непосредственно рядом с границей мобилизовал людей, и весной 1919 г. монгольский отряд с численностью 250-300 человек дислоцировался в южных районах Тувы. «Появление в Туве крупного и достаточно боеспособного отряда во главе с видным военачальником отвечало политике китайский экспансии на бывшие окраины Цинской империи» (История Тувы, 2007: 93). Содержание и снабжение монгольского отряда легло на плечи простых тувинских аратов. Так, из Хемчикского хошуна было выделено 47 КРС, 232 МРС, 360 ланов, 28 охранников, а каждый русский крестьянский двор должен был сдать 5 пудов пшеничной муки.

3 июля 1919 г. Максаржав без труда занял перевал Калдак-Хамар, единственную дорогу в Белоцарск, которую охраняли русские дружинники. В бою погиб- 
ли около 20 русских, монголам достались их снаряжения и лошади. Здесь Максаржав для охраны оставил 30 солдат с оружием (Мягмарсамбуу, 2011: 70-71). Как вспоминал И. Шагдыржап, перед наступлением в Белоцарск, на перевале Максаржав провел ритуал освещения боевого знамени кровью обезглавленного русского казака (НА ТИГПИ. Р/Ф. Д. 274. Л. 43-44). Кстати сказать, такой же ритуал он провел и перед осаждением крепости Кобдо в 1912 г.

Перед Белоцарском он остановился для короткого отдыха в районе оз. Чагытай. Здесь он хотел заручиться поддержкой у местного населения и в результате проведения определенной работы сумоны Иргит, Чооду, Оюннар и Шалык объявили о принятии их в подданство Богдо-гэгээну.

В столицу Максаржав прибыл 18 июля и потребовал от русского населения в течение 45 дней покинуть пределы Тувы. Позднее это требование было изменено: русским было предложено принять монгольское подданство и беспрекословно подчиниться монгольскому представителю. И только прибытие сибирской партизанской армии П. Е. Щетинкина и А. Д. Кравченко остановили далеко идущие планы монгольского представителя. Командиры красных партизан провели переговоры с Максаржавом в результате которого был создан орган под названием «Комиссия по делам русских с Монголией». Но сразу после их ухода монголы вновь вернулись к проводимой ранее политике.

«Как только армия красных, - писал И. Г. Сафьянов, - перевалила обратно в Минусинский край, монгольский штаб резко изменил свое отношение к трудящимся русской колонии. Он потребовал, чтобы русские колонии в 1,5-месячный срок очистили занимаемые ими поселки и выехали со всем своим имуществом в Усинский округ» (Сафьянов, 2012: 143). Но Комиссии удалось урегулировать данный вопрос с монголами только после принятия унизительных для них условий.

Осенью 1919 г. у Максаржава обострилось хроническое заболевание, о чем он сообщил в свое правительство. Но просьбу оставили без удовлетворения. Тогда он вызвал к себе бейсе Жамсрана из Кобдо и передал ему свои полномочия, а сам возвратился в Монголию (Мягмарсамбуу, 2011: 73). Монгольский военный отряд совершил несколько походов в поселки, где проживали русские и даже «преследуя отступавших партизан, ворвался в с. Верхне-Усинское, но партизаны совместно с усинскими крестьянами вынудили монгольских солдат с чувствительными потерями отступить» (История Тувы, 2007: 108).

В конце 1919 г. в Монголии был оформлен «добровольный» отказ Богдо-гэгэна от автономии. Сразу после этого вышел приказ китайского комиссара, в котором указывалось, что в связи с последними событиями монголам до приезда китайского отряда следует вернуться домой. 


\section{Заключение}

Таким образом, после революций в России воспользовавшись непростой ситуацией, китайцы и монголы предприняли попытку вернуть Туву под свое влияние. Их действия привели к дальнейшей разрозненности тувинских хошунов и сумонов, лишним расходам по содержанию военных интервентов.

\section{СПИСОК ЛИТЕРАТУРЫ}

Аранчын, Ю. Л. (1982) Исторический путь тувинского народа к социализму. Новосибирск : Наука. 337 с.

Белов, Е. А. (1999) Россия и Монголия. М. : ИВ РАН. 238 с.

История Тувы (2007) / под ред. В. А. Ламина. Новосибирск : Наука. Т. II. 428 с.

Моллеров, Н. М. (2014) Протекторат России над Тувой в 1914-1924 гг. (историко-правовой аспект) // Единая Тува в единой России: история, современность, перспективы. Материалы международной научной конференции, посвященной 100-летию единения России и Тувы. Абакан: Хакасское книжное изд-во. Ч. I. C. 14-18.

Мягмарсамбуу, Г. (2011) Домогт жанжин ардын Хатан баатар С. Магсаржав (1878-1927 он). Улаанбаатар. 281 с. (На монг. яз.).

Очур, В. Ч. (1967) Великий Октябрь и Тува. Кызыл: Тувин. книж. изд-во. 145 с.

Самдан, А. А. (2014) Правовое регулирование административного и судебного устройства тувинцев в период протектората России на Урянхайским краем (Тувой) // Единая Тува в единой России: история, современность, перспективы. Материалы международной научной конференции, посвященной 100-летию единения России и Тувы. Абакан : Хакасское книжное изд-во. Ч. 1. С. 78-80.

Сафьянов, И. Г. (2012) Тува в прошлом : к 90-летию Тувинской народной республики. М. : б/и. Т. ІІ. Повесть о жизни. Гражданская война в Туве. 315 с.

Сейфулин, Х. М. (1956) К истории иностранной интервенции и гражданской войны в Туве (1918-1921 гг.). Кызыл : Тувин. книж. изд-во. 119 с.

Сердобов, Н. А. (1985) Коминтерн и революционная Тува. Кызыл : Тувин. книж. изд-во. 238 с.

Собрание архивных документов о протекторате России над Урянхайским краем - Тувой (к 100-летию исторического события) (2014) / сост. Т. А. Бондаренко и др. Кызыл : ТИГИ. 479 с. 


\section{REFERENCES}

Aranchyn, Iu. L. (1982) Istoricheskii put' tuvinskogo naroda $k$ sotsializmu [The historical path of the Tuvan people to socialism]. Novosibirsk, Nauka. 337 p. (In Russ.).

Belov, E. A. (1999) Rossiia i Mongoliia [Russia and Mongolia]. Moscow, IV RAN. 238 p. (In Russ.).

Istoriia Tuvy [The History Of Tuva] (2007) / ed. by V. A. Lamin. Novosibirsk, Nauka. Vol. II. 428 p. (In Russ.).

Mollerov, N. M. (2014) Protektorat Rossii nad Tuvoi v 1914-1924 gg. (istorikopravovoi aspekt) [Russian protectorate over Tuva in 1914-1924: historical and legal aspects]. In: Edinaia Tuva v edinoi Rossii: istoriia, sovremennost', perspektivy. Materialy mezhdunarodnoi nauchnoi konferentsii, posviashchennoi 100-letiiu edineniia Rossii $i$ Tuvy [United Tuva in United Russia: history, modernity and prospects. Proceedings of the international research conference devoted to 100th anniversary of the unification of Russia and Tuva]. Abakan, Khakasskoe knizhnoe izd-vo. Vol. I. Pp. 14-18. (In Russ.).

Miagmarsambuu, G. (2011) Domogt zhanzhin ardyn Khatan baatar S. Magsarzhav (1878-1927 on). Ulaanbaatar. 281 s. (In Mong.).

Ochur, V. Ch. (1967) Velikii Oktiabr' i Tuva [The Great October and Tuva]. Kyzyl, Tuvin. knizh. izd-vo. 145 p. (In Russ.).

Samdan, A. A. (2014) Pravovoe regulirovanie administrativnogo i sudebnogo ustroistva tuvintsev v period protektorata Rossii na Uriankhaiskim kraem (Tuvoi) [Legal regulation of administrative and judicial system in Tuva under the Russian protectorate over Uriankhai krai (Tuva)]. In: Edinaia Tuva $v$ edinoi Rossii: istoriia, sovremennost', perspektivy. Materialy mezhdunarodnoi nauchnoi konferentsii, posviashchennoi 100-letiiu edineniia Rossii i Tuvy [United Tuva in United Russia: history, modernity and prospects. Proceedings of the international research conference devoted to 100th anniversary of the unification of Russia and Tuva]. Abakan, Khakasskoe knizhnoe izd-vo. Vol. 1. Pp. 78-80. (In Russ.).

Saf'ianov, I. G. (2012) Tuva v proshlom : $k$ 90-letiiu Tuvinskoi narodnoi respubliki [Tuva in the past: 90th anniversary of Tuvan People's Republic]. Moscow. Vol. II. Povest' o zhizni. Grazhdanskaia voina $v$ Tuve [A tale of life. The civil war in Tuva]. 315 p. (In Russ.).

Seifulin, Kh. M. (1956) K istorii inostrannoi interventsii i grazhdanskoi voiny $v$ Tuve (1918-1921 gg.) [The history of foreign intervention and civil war in the Republic of Tuva (1918-1921)]. Kyzyl, Tuvin. knizh. izd-vo. 119 p. (In Russ.).

Serdobov, N. A. (1985) Komintern i revoliutsionnaia Tuva [The Comintern and the revolutionary Tuva]. Kyzyl, Tuvin. knizh. izd-vo. 238 p. (In Russ.).

Sobranie arkhivnykh dokumentov o protektorate Rossii nad Uriankhaiskim kraem - Tuvoi (k 100-letiiu istoricheskogo sobytiia) [A collection of archival documents on 
Russian protectorate over Uriankhai krai (Tuva): the 100th anniversary of an event in history] (2014) / comp. by T. A. Bondarenko et al. Kyzyl, TIGI. 479 p. (In Russ.).

Submission date: 05.10.2017.

\section{Для цитирования:}

Самдан А. А. Вторжение китайского и монгольского отрядов в Туву (1918-1919 гг.) [Электронный ресурс] // Новые исследования Тувы. 2017, № 4. URL: https://nit.tuva. asia/nit/article/view/744 (дата обращения: дд.мм.гг.). DOI: 10.25178/nit.2017.4.9

\section{For citation:}

Samdan A. A. The Invasion of Tuva by Chinese and Mongolian Army Units (19181919). The New Research of Tuva, 2017, no. 4 [on-line] Available at: https://nit.tuva.asia/nit/ article/view/744 (accessed: ...). DOI: 10.25178/nit.2017.4.9 